\title{
Braden Scale in pressure ulcer risk assessment
}

\author{
A Escala de Braden na avaliação do risco para lesão por pressão \\ La Escala de Braden en la evaluación del riesgo de lesión por presión
}

Ricardo Clayton Silva Jansen'
ORCID: 0000-0002-6392-8100

Kedyma Batista de Almeida Silva'

ORCID: 0000-0003-3585-5669

Maria Edileuza Soares Moura' ORCID: 0000-0002-2550-8383

'Universidade Estadual do Maranhão. Caxias, Maranhão, Brazil

How to cite this article:

Jansen RCS, Silva KBA, Moura MES. Braden Scale in pressure ulcer risk assessment. Rev Bras Enferm. 2020;73(6):e20190413. doi: http://dx.doi.org/10.1590/0034-7167-2019-0413

Corresponding author:

Ricardo Clayton Silva Jansen E-mail: ricardojansen_20@hotmail.com

EDITOR IN CHIEF: Antonio José de Almeida Filho ASSOCIATE EDITOR: Alexandre Balsanelli

Submission: 08-20-2018 Approval: 01-07-2020

\begin{abstract}
Objective: To analyze the applicability of the Braden Scale to individuals admitted to an Intensive Care Unit (ICU) with the nursing diagnosis Impaired Physical Mobility, in its prediction potential to develop pressure ulcer (PU). Methods: A cross-sectional, quantitative study that evaluated all patients hospitalized in an ICU between November 2016 and February 2017, with the Braden Scale. Results: The prevalence of PU was $35.8 \%$ (24/67), in male individuals $58.3 \%$ (14/24), diagnosed with ischemic CVA 51.9\% (12/27), and with hemorrhagic CVA 7.4\% (2/27). Among patients classified at severe risk of developing pressure ulcer, $83.3 \%(20 / 53)$ developed it, and 76.7\% (33/53) did not develop it. Conclusion: The performance of the Braden Scale showed a balance between sensitivity and specificity, confirming it as a better predictive risk assessment instrument in this group of patients.

Descriptors: Comprehensive Health cCare; Critical Care; Nursing Care; Nursing Assessment; Nursing Diagnosis.
\end{abstract}

\section{RESUMO}

Objetivo: Analisar a aplicabilidade da Escala de Braden a indivíduos internados em Unidade de Terapia Intensiva (UTI) com o diagnóstico de enfermagem "mobilidade do leito prejudicada", em seu potencial de predição do desenvolvimento de lesão por pressão (LPP). Métodos: Estudo transversal, quantitativo, que avaliou, com a Escala de Braden, pacientes internados em uma UTI entre novembro de 2016 e fevereiro de 2017. Resultados: A prevalência de lesão por pressão foi $35,8 \%$ (24/67), no sexo masculino (58,3\%; 14/24), com diagnóstico de acidente vascular encefálico (AVE) isquêmico $(51,9 \% ; 12 / 27)$ e com acidente vascular encefálico hemorrágico $(7,4 \% ; 2 / 27)$. Dentre os pacientes classificados com risco muito alto de desenvolver lesão por pressão, 83,3\% (20/53) a desenvolveram e 76,7\% (33/53) não a desenvolveram. Conclusão: 0 desempenho da Escala de Braden apresentou equilíbrio entre sensibilidade e especificidade, mostrando-se melhor instrumento preditivo de risco nessa clientela.

Descritores: Assistência Integral à Saúde; Cuidados Críticos; Cuidados de Enfermagem; Avaliação em Enfermagem; Diagnósticos de Enfermagem.

\section{RESUMEN}

Objetivo: Analizar La aplicabilidad de la Escala de Braden a individuos internados en UTI con el diagnóstico de enfermería, movilidad del lecho perjudicada, en su potencial de predicción para desarrollar lesión por presión. Métodos: Estudio transversal, cuantitativo, que evaluó, con la Escala de Braden, todos los pacientes internados en una UTI entre noviembre de 2016 a febrero de 2017. Resultados: La prevalencia de lesión por presión fue 35,8\% (24/67), 58,3\% (14/24) del sexo masculino, el diagnóstico AVE-isquémico representó el 51,9\% (12/27), el AVE-hemorrágico $7,4 \%(2 / 27)$ y la crisis convulsiva $3,7 \%$ (1/27). Entre los pacientes clasificados con riesgo muy alto para desarrollar lesión por presión 83,3\% (20/53) La desarrollaron y el 76,7\% (33/53) no la desarrollaron. Conclusión: El desempeño de la Escala de Braden presentó equilibrio entre sensibilidad y especificidad, mostrándose mejor instrumento predictivo de riesgo en esa clientela. Descriptores: Atención Integral de Salud; Cuidados Críticos; Atención de Enfermería; Evaluación en Enfermería; Diagnóstico de Enfermería. 


\section{INTRODUCTION}

Nursing is a science whose essence is the provision of assistance and care. As a science, it contributes to the promotion, prevention, recovery, and rehabilitation of the patient's health, holistically. Among its responsibilities and duties, it is crucial to ensure nursing care free of damages resulting from malpractice, negligence, or imprudence ${ }^{(1)}$.

Patient safety is a global public health challenge, which has led the World Health Organization, in partnership with the International Classification for Patient Safety (ICPS), to characterize it as the act of avoiding, preventing or improving adverse results or injuries caused in the medical-hospital care process $s^{(2)}$.

In 2013, the Ministério da Saúde (Ministry of Health) instituted the Programa Nacional de Segurança do Paciente (PNSP -National Patient Safety Program), which, through Ordinances GM / MS 1,377 -July 9, 2013 - and Ordinance 2,095 -September 24, 2013 -, instituted the following basic protocols for patient safety in health services: correctly identifying the patient; improve communication between health professionals; improve safety in the prescription, use, and administration of medications; ensure safe surgery; hand hygiene to avoid infections, and reduce the risk of falls and pressure ulcers ${ }^{(3)}$.

In Brazil, according to the National Report on Incidents Related to Health Care - consolidated from the National Health Surveillance System - in the period from January 2014 to July 2017 - the Patient Safety Centers notified 134,501 incidents, of these, $23,722(17.6 \%)$ corresponded to notifications of pressure ulcers (PU), constituting, in this period, the third type of event most frequently reported in Brazilian health services. About 3,771 never events were also reported, of which 2,739 (72.6\%) were due to stage $3 \mathrm{PU}$, and $831(22 \%)$ resulting from stage $4 \mathrm{PU}$, with 34 (4.4\%) of these cases evolving to death due to $\mathrm{PU}^{(4)}$.

The nursing process bases the organization, in a systematic way, for the provision of care by the nursing profession. Its documentation aims to describe, explain, and understand the patient's needs in relation to the nursing professional's practice ${ }^{(5)}$. Thus, the multidisciplinary health team, including the nursing team, needs to use instruments that can daily classify patients at higher risk of PU and establish preventive measures.

It is possible to define PUs as injuries located on the skin, tissue, muscle, and even bone, caused by intense or continuous pressure, leading to decreased blood circulation and, consequently, to death and skin necrosis ${ }^{(6)}$. The recent changes in nomenclature released by the National Pressure Ulcer Advisory Panel and the European Pressure Advisory Panel have reclassified PU, which now has six stages.

Stage 1 PU includes an injury with intact skin, with a localized area that does not whiten. In stage 2 , the defining characteristic is the loss of the skin in its partial thickness, with exposure of the dermis, pink or red color, and moisture in the wound bed, which may present intact blisters. Stage 3 is identified by loss of skin in its full thickness, the involvement of subcutaneous tissues with curled edges. In stage 4, there is skin loss in its total thickness, tissue loss, exposure of underlying muscles, bones, or tendons. The most compromised stages of the tissue are from non-classifiable PU, in which there is loss of the skin in its total thickness and visible tissue loss, but whose stage cannot be confirmed since it is covered by slough; finally, in deep tissue $\mathrm{PU}$, there is dark red, brown or purple discoloration, persistent and that does not whiten, injury with a darkened bed or blisters with bloody exudate ${ }^{(7)}$.

In this context, the identification of individual risk factors is useful to carry out a Systematization of Nursing Assistance in care and therapy ${ }^{(8)}$. The use of scales for assessing the risk of developing PU is of great value for nursing and provides systematic care planning for hospitalized patients, which facilitates the diagnosis, treatment, and prevention of these injuries ${ }^{(9)}$. The Braden Scale is one of the instruments that help to detect the risks of developing $\mathrm{PU}$, in addition to enabling nursing professionals to design better the preparation of the care prescriptions offered these patients ${ }^{(10)}$.

The risk assessment for PU offers the opportunity to share the information obtained within the interdisciplinarity scope. It is the multidisciplinary health team's contribution to care to adopt measures aimed at preventing and treating, educating patients and family members, and the institution's participation in the promotion of conditions appropriate to the needs of each individual ${ }^{(11)}$.

Thus, the concern with the quality of nursing care provided to hospitalized and critically ill patients is a significant challenge for the entire multidisciplinary team that works in the intensive care unit (ICU). The prevention of PU must be a careful quality practice, as well as a priority action. Therefore, it is necessary to use strategies that can involve the institution and the multidisciplinary team that works in the ICU, giving priority to nurses who are directly and continuously offering assistance to this patient ${ }^{(12)}$. Thus, the Braden Scale can assist in detecting the risk that patients with impaired mobility have to develop PU.

\section{OBJECTIVE}

To analyze the applicability of the Braden Scale to patients admitted to the ICU who has a nursing diagnosis of impaired bed mobility, considering its potential to predict the development of pressure ulcers.

\section{METHOD}

\section{Ethical aspects}

The Research Ethics Committee of the Universidade Federal do Maranhão (UFMA - Federal University of Maranhão).

\section{Research approach and modality}

A cross-sectional study, with a quantitative approach, carried out in the ICU of a general hospital, in Maranhão, over 4 months. The studied hospital has 112 beds for hospitalization, 12 of which are ICU.

\section{Reason for choosing}

From the activities developed in the ICU of that hospital, we found the impact of PU on quality of life and the course of 
hospitalization of patients affected by it. The opportunity to broaden the perception of the care provided to patients was essential to provide reflection and a critical view on the susceptibility to PU. We highlight the relevance and the need to assess the applicability of the Braden Scale to identify individuals at risk of developing PU promptly.

\section{Participants: inclusion and exclusion criteria}

The study sample consisted of 67 individuals admitted to the ICU. Inclusion criteria were individuals over 18 years old, admitted to the ICU, identified by the researcher as individuals who met the NANDA criteria of the nursing diagnosis "impaired bed mobility."The exclusion criteria were patients with diagnosed PU; and admitted to the ICU.

\section{Data collection}

Data collection took place from February 28 to June 30, 2017, using a questionnaire that collected clinical and sociodemographic data; and the Braden Scale, which the researcher applied from the moment the individual was admitted to the ICU and every 24 hours, to assess and classify the risk of developing PU.

The dependent variable of the study was "impaired bed mobility," defined according to the taxonomy of the North American Nursing Diagnosis Association (NANDA) as "limitation to move independently from one position to another in the bed."This nursing diagnosis has as a defining characteristic the impaired ability: to reposition in bed, turn from side to side, move from the prone to the supine position, from the sitting position with the legs extended to the supine position, from the sitting position to the supine position, from the supine position to the prone position, from the supine position to the sitting position with the legs extended and from the supine position to the sitting position. The factors related to this nursing diagnosis are poor knowledge, deconditioning, pain, insufficient muscle strength, environmental limitations (e.g., bed size, type of bed, treatment equipment, immobilizers), sedative medications, obesity, and cognitive impairment, musculoskeletal and neuromuscular ${ }^{(13)}$.

The independent variables were age, gender, color, marital status, schooling, profession, family income, general data (beginning of hospitalization, the reason for hospitalization, medical diagnosis), clinical data (comorbidities and medications in use). The risk predictor variables in the Braden Scale were also considered: sensory perception, moisture, activity, mobility, nutrition, friction, and shear.

\section{Data Analysis}

For data analysis, we used the following software: Word for Windows (Version 8.0), as a word processor, and Microsoft Office Excel (Version 8.0.0.0), for the preparation of tables and graphs. Quantitative data, coming from questions of the sociodemographic profile and the Braden Scale, were tabulated and arranged in order to facilitate the analysis and interpretation of the results.
Thus, with the numerical information in hand, a database was created using the Statistical Package for the Social Sciences - SPSS (version 20.0 for Windows) software, later consolidated using descriptive statistics techniques (absolute and relative frequencies). Also, statistical tests were carried out, such as Pearson's chi-square, to verify the association between categorical variables, and Student's $t$-test, to compare the means of quantitative variables, in which the value of $5 \%$ was adopted as the level of significance. In the statistical analysis, to identify the chance of occurrence of the events (OR - Odds Ratio), univariate analysis was performed, considering the variable for patients who developed PU.

\section{RESULTS}

The prevalence of PU was $35.8 \%$ (24/67). The analysis of the sociodemographic characteristics of individuals who developed and who did not develop PU (Table 1) showed a male predominance, with PU (14/24; 58.3\%) and without PU (21/43; 48.8\%). The average age of those who developed PU was 76.5 years (ranging from 60 to 100 years); the average age of those who did not develop PU was 65 years (ranging from 19 to 96 years), with $p$ value $<0.001$, which shows the statistical significance of age for the development of PU.

As for the length of stay, the average stay for those who developed PU was eight days (ranging from 4 to 33 days); in the group that did not develop PU, this average was three days (ranging from 2 to 10 days), and the variable had $p$ value $<0.001$, showing the positive influence of the length of stay in the ICU for the development of PU.

A total of 24 individuals developed $36 \mathrm{PU}$ (some had more than one PU). PU located in the heel region represented $55.6 \%$ (20/36); in the sacral region, stage I, represented $33.3 \%(12 / 36)$ and in the sacral region, stage II, $11.1 \%(4 / 36)$.

In this study, pardos (brown) individuals represented $41.7 \%$ (10/24) of those who developed PU and $44.2 \%$ (19/43) of those who did not develop it. Among the clinical conditions that justified admission to the ICU, those related to cardiovascular impairment were responsible for $75 \%$ (18/24) of the cases that developed PU and $51.3 \%$ (20/43) of those who did not develop it.

In relation to drugs with the potential to alter the level of consciousness, hypoglycemic agents were administered to $41.7 \%$ (10/24) of the individuals who developed PU; and antipsychotics, $55.8 \%$ (24/43) of those who did not develop PU.

As for the defining conditions for the nursing diagnosis "impaired bed mobility," the group with impaired ability to move from side to side represented $83.3 \%$ (20/24) of those who developed PU. As for the conditions related to the nursing diagnosis of individuals with "insufficient muscle strength," $62.4 \%$ of them (15/24) developed PU, and 53.5\% (23/43) did not develop it.

Regarding the assessment of risk of developing PU, according to the Braden Scale, individuals classified as having a very high risk of developing PU and who developed it represented $83.3 \%$ (20/24), whereas those classified as having a very high risk but did not develop it were $76.7 \%$ (33/43) (Table 2).

Individuals who developed PU with a diagnosis of ischemic CVA represented 58.3\% (14/24); hemorrhagic CVA, 8.3\% (2/24); and convulsive crisis, 4.2\% (1/24); OR = 6.75 (Table 3). 
Table 1 - Sociodemographic and clinical characteristics of patients who developed and those who did not develop pressure ulcers, Caxias, Maranhão, Brazil, 2017

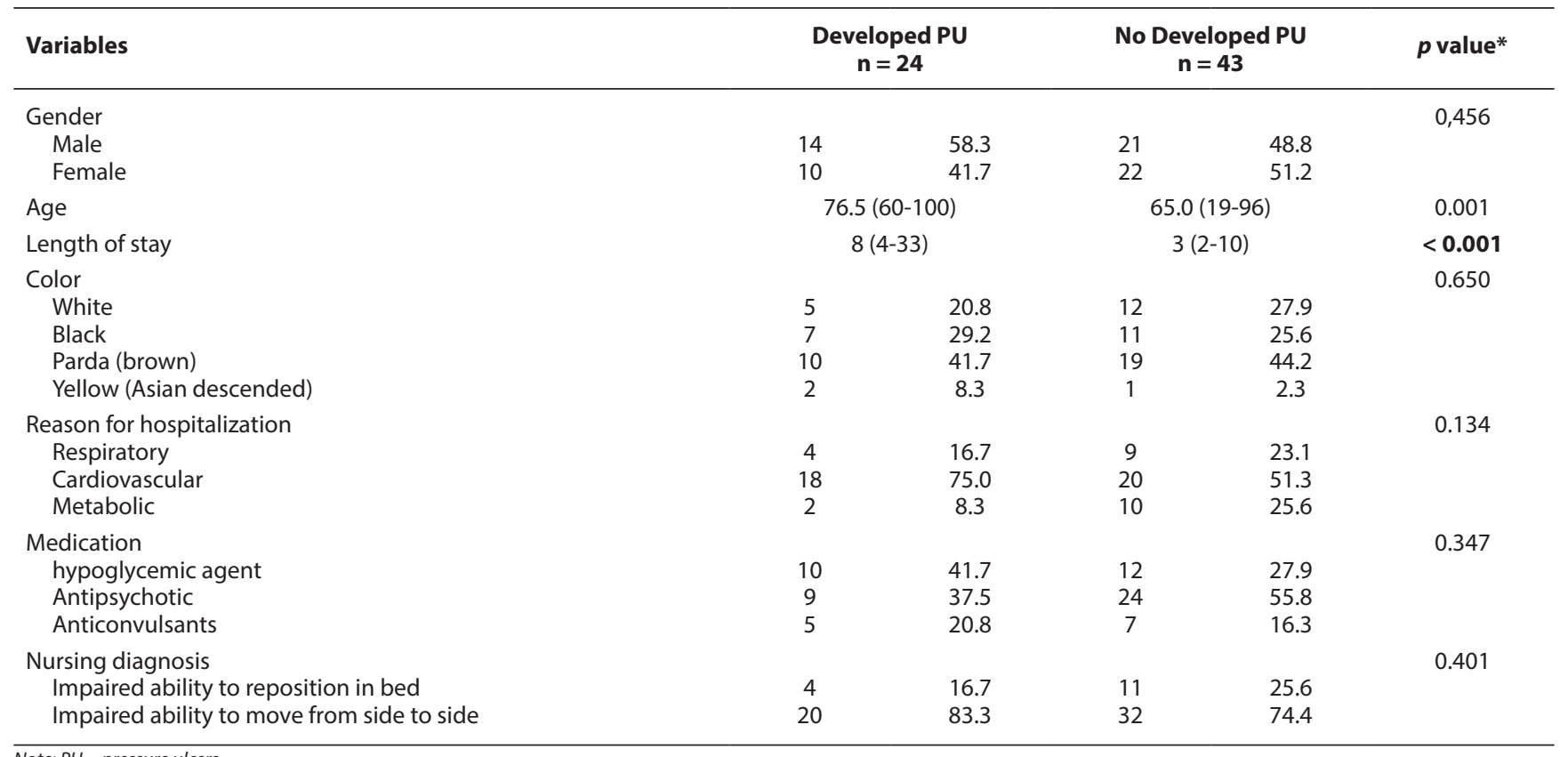

Note: $P U=$ pressure ulcers.

Table 2 - Assessment of the risk of developing pressure ulcers according to the Braden Scale, in the Caxias Hospital, Maranhão, Brazil, 2017

\begin{tabular}{lccccc}
\hline & \multicolumn{2}{c}{ Developed PU } & \multicolumn{2}{c}{ Did not develop PU } & $\begin{array}{c}\boldsymbol{p} \\
\text { value }\end{array}$ \\
& $\mathbf{n}$ & $\%$ & $\mathbf{n}$ & $\%$ & \\
\hline Braden scale & & & & & 0.675 \\
$\quad$ Moderate risk & 0 & 0.0 & 1 & 2.3 & \\
$\quad$ High Risk & 4 & 16.7 & 9 & 20.9 & \\
$\quad$ Severe risk & 20 & 83.3 & 33 & 76.7 & \\
\hline Note: $P U=$ pressure ulcers. & & & &
\end{tabular}

Note: $P U=$ pressure ulcers.

Table 3 - Correlation between medical diagnosis and the risk of developing pressure ulcer, Caxias, Maranhão, Brazil, 2017

\begin{tabular}{lccccccc}
\hline \multirow{2}{*}{ Medical diagnosis } & \multicolumn{2}{c}{ Sim LPP } & \multicolumn{2}{c}{ Não LPP } & OR & \multirow{2}{*}{ IC 95\% } \\
& $\mathbf{n}$ & $\%$ & $\mathbf{n}$ & $\%$ & & \\
\hline CVA-I & 14 & 58.3 & 14 & 32.6 & 6.75 & $1.86-24.41$ \\
Pneumonia & 3 & 12.5 & 6 & 13.9 & 3.38 & $0.59-19.21$ \\
CVA-H & 2 & 8.3 & 2 & 4.7 & 6.75 & $0.73-62.37$ \\
Acute respiratory distress & 2 & 8.3 & 5 & 11.6 & 2.7 & $0.38-18.92$ \\
Cirrhosis & 1 & 4.2 & 2 & 4.7 & 3.38 & $0.25-46.36$ \\
Convulsive crisis & 1 & 4.2 & 1 & 2.3 & 6.75 & $0.34-130.79$ \\
Other: & 1 & 4.2 & 13 & 30.2 & 1 & - \\
Total & 24 & 100.0 & 43 & 100.0 & - & - \\
\hline
\end{tabular}

Note: $P U=$ pressure ulcers.

\section{DISCUSSION}

There was a higher occurrence of PU among men and older adults. The risk of developing PU had a higher percentage in the elderly and male individuals ${ }^{(14)}$. A study that investigated the calibration power of the Braden Scale in predicting PU the development in a university hospital in China showed a prevalence of $61.2 \%$ among males. The age analysis showed an average of over 60 years old; this characteristic is associated with the fact that the elderly have physiological changes typical of age ${ }^{(15)}$.
Unfortunately, the occurrence of adverse events in the intensive care setting is usual. It is noteworthy that one of the most common consequences resulting from extended hospital stays is the appearance of skin injuries, primarily PU. The incidence increases proportionally to the combination of risk factors, among which are advanced age and bed restriction ${ }^{(16)}$.

The average length of stay, as another important aspect of the cause of changes or complications in hospitalized patients, was surprisingly long for patients with PU, compared to those without PU. A study on the prevalence of PU in a reference ICU in the state of Rio Grande do Norte corroborates such findings, as it found that among individuals between 1 and 15 days of hospitalization, 10 (34.5\%) presented $\mathrm{PU}^{(17)}$.

As for the location of the injuries, the results showed the predominance of $\mathrm{PU}$ in the calcaneus and sacral region, considered as places of support when in the supine or lateral position, which is common among critically ill patients. In an investigation conducted in a hospital in Espírito Santo, the accuracy of the Braden and Waterlow risk assessment scales was verified in 87 critically inpatients: the research showed that 38 individuals developed PU, $72 \%$ in the I stage, in the heel region; and $47 \%$ in stage II, in the sacral region ${ }^{(18)}$.

There was a higher occurrence of PU among pardos (brown) individuals. This reality can be justified, using data from the Instituto de Pesquisa Econômica Aplicada (IPEA -Institute of Applied Economic Research), by the fact that the 2010 Census identified an increase in the proportion of the black population in all federative units, which was higher than the national variation (13.6\%) in eight states. Maranhão ranks as one of the states with the highest participation of black individuals and pardos, around $76 \%$ of the total population ${ }^{(19)}$.

Clinically, underlying and associated diseases predominated in patients with PU, pointing to those morbidities that compromise 
the cardiovascular system. A study conducted with adult patients hospitalized in Pará found that the Braden Scale scores, and sub-scores predominated in the clinical condition resulting from cardiovascular impairment $(18 \%)^{(14)}$. A study at the Intermediate Surgical Intensive Care Unit and the Intensive Care Center, of a university hospital in Espírito Santo, found that the disease caused by cardiovascular causes represented $21.05 \%{ }^{(18)}$.

As for the drugs used in the study, mainly for continuous use (sedatives), the study concluded that they could also contribute to the development of PU. An analysis of the evaluation of the implementation of a protocol for the prevention of PU in ICU patients at a teaching hospital in the city of São Paulo found that, among all inpatients, 35.3\% used hypoglycemic agents and 55, $8 \%$ used some sedative medication ${ }^{(20)}$.

It is important to note that patient safety initiatives in Brazil are relatively recent. With the establishment of a National Patient Safety Program, Brazil is committed to developing public policies and practices aimed at patient safety, including reducing the risk of PU. However, there is still a high incidence of adverse events in Brazilian hospitals. A study showed a high incidence of adverse events that could be avoided, with PUs representing $18.4 \%$ of the events responsible for prolonging patients' stay in hospitals ${ }^{(2)}$.

Besides, the occurrence of PU is a common phenomenon in various health care settings and affects, in particular, critically ill patients, so that it contributes to the increased risk of hospital complications. Despite scientific and technological advances and the improvement of services and health care, the incidence varies from $23.1 \%$ to $59.5 \%$, especially in patients admitted to the $\operatorname{ICU}^{(18,20)}$

Despite being one of the international goals for patient safety, publications on the incidence of $\mathrm{PU}$ at national and international levels are still infrequent due to the influence of the results of these analyses on the classification of service quality. In Brazil, these studies are common in some states, as is the case in São Paulo, but there is a deficit in the others ${ }^{(21)}$.

With regard to the diagnosis of the impaired capacity of "turning from side to side," this group was the one that most developed PU. A study carried out at the Coronary ICU of Hospital das Clínicas of Universidade Federal do Triângulo Mineiro (Federal University of Triângulo Mineiro), identified 44 most frequent nursing diagnoses, among them the Activity/Rest domain had the highest concentration of diagnoses (54.69\%), one of the most frequent is impaired bed mobility (7.08\%). Concerning this diagnosis, the related factors were pain, obesity, insufficient muscle strength, presence of a drain, the presence of an introducer, sedatives, and neuromuscular damage ${ }^{(22)}$.

In clinical practice, the identified nursing diagnoses can support the construction of a nursing data collection instrument for patients hospitalized in the ICU, as they favor the investment of professionals in the search for evidence-based interventions, for the discussion of necessary actions, in order to meet the patients' real health needs ${ }^{(23)}$.

In this study, the Braden Scale showed a better balance between sensitivity and specificity, showing itself to be a better risk predictive tool in this group of patients. A study carried out in a hospital in South Korea, which evaluated and calibrated the Braden Scale in the prediction of PU development, revealed a sensitivity of $85.7 \%$ and specificity of $64.6 \%{ }^{(15)}$. An Intermediate Surgical Intensive Care Unit and Intensive Care Center in Espírito Santo used the Braden Scale and detected, in the first evaluation, a sensitivity of $41 \%$ and a specificity of $21 \%{ }^{(18)}$.

Diseases of the neurological system (ischemic CVA) were identified as the most frequent conditions of hospitalization. A study developed in the ICU of a private hospital in Curitiba, in order to analyze the clinical profile of patients with and without $\mathrm{PU}$, found that diseases of the neurological system occupied the first position among the morbidities of patients in need of intensive care, which represents $60 \%$ of patients who developed PU during hospitalization ${ }^{(24)}$.

These results emphasize the need to reinforce specific guidelines aimed at all professional categories of health services, aimed at prioritizing safe care. One of these guidelines refers to safety competencies launched in Canada, which focus on multidisciplinary responsibility for adequate patient safety; all health professionals should value knowledge identification, skills, and behaviors. Such as contributing to the patient safety culture; teamwork; communicate efficiently; manage security risks; optimize human and environmental factors; recognize and reveal adverse events as well as respond to them ${ }^{(25)}$.

Although there is effective performance of the nursing team in the application of the Braden Scale, in the timely identification of patients who are at risk of developing PU, there is still a need to establish strategies for its prevention and always evaluated the adherence to the established protocol. Such measures aim to minimize complications for the patient and, in turn, reduce the incidence of the disease, reinforcing the actions of the protocol for the prevention of skin injuries that need to be intensified.

Health facility managers must strive to promote a culture of patient safety; in order for this to happen, each employee is expected to be prepared to identify the potential dangers and make the necessary changes, that is, elimination, reduction, and control of risks, to provide safe assistance.

\section{Study Limitations}

Among the limitations of this study, we can highlight the sample size, as a more significant number of individuals would contribute to a better determination of the risk of developing PU.

\section{Contributions to the nursing field}

Studies with this theme can deepen discussions in the academic and scientific environment in order to expand knowledge about the National Patient Safety Program, as well as the dissemination of the use of predictive scales for the prevention of PU and skills for clinical practice. As for the benefits to patients, the shortest length of stay, less damage, and better quality of life are highlighted; for health institutions, the decrease in hospital costs.

\section{CONCLUSION}

In this study, the Braden Scale showed a better balance between sensitivity and specificity, showing itself to be a better risk predictive tool in this group of patients. Among the individuals 
evaluated, those at severe risk were more likely to trigger some stage of PU. The results point to the use of educational strategies on the theme "patient safety" for all levels of professionalization/ training, from undergraduate to different postgraduate levels, in the most diverse categories of health professionals.

We admit that preventive actions for PU start with the patient's admission, the moment in which the nurse must make use of predictive risk scales and plan the measures that meet the needs of that person. The use of predictive scales is a remarkable intervention in the preventive process, constituting an effective mechanism for reducing the prevalence of PU among hospitalized patients, especially critical patients. However, the approach to patients at risk of PU must be interdisciplinary and give rise to the commitment of different professional categories, following the care logic of the Single Health System.

In tracking individuals vulnerable to the onset of PU, it is essential to adopt instruments with reliable psychometric and therapeutic indexes, in order to anticipate the application of preventive measures. Therefore, we suggest carrying out further research with these measurement instruments, with a different design, larger sample size, and with patients affected by other conditions, thus contributing to the correct determination of the risk of PU and improvement in its prevention.

\section{ACKNOWLEDGMENTS}

Bearing in mind that patient safety and, therefore, the problem of pressure ulcers is multidisciplinary and interdisciplinary, it is essential to highlight the relevance of professionals working in the ICU of the general hospital where we conducted the study. We express here our gratitude to the medical, nursing, nutrition, and physiotherapy staff, as they all contributed in an essential way to the construction of this study, providing comprehensive care to inpatients.

\section{REFERENCES}

1. Conselho Federal de Enfermagem. Resolução COFEN № 564/2017 [Internet]. 2017 [cited 2019 May 24]. Available from: http://www.cofen. gov.br/resolucao-cofen-no-5642017_59145.html.

2. Mendes W, Pavao ALB, Martins M, Moura MLO, Travassos C. Características de eventos adversos evitáveis em hospitais do Rio de Janeiro. Rev Assoc Med Bras. 2013;59(5):421-8. doi: 10.1016/j.ramb.2013.03.002

3. Fraga IMN, Nascimento ACA, Santana NA, Correia AS, Melo IA. A Comunicação Efetiva no Contexto Hospitalar: uma Estratégia para a Segurança do Paciente [Internet]. 2017 [cited 2019 May 24];1 (1). Available from: https://eventos.set.edu.br/index.php/cie/article/view/5573/2410

4. Agência Nacional de Vigilância Sanitária. Relatório nacional de incidentes relacionados à assistência à saúde: boletim segurança do paciente e qualidade em serviços de saúde [Internet]. 2017 [cited 2019 May 24]. Available from: https://www20.anvisa.gov.br/segurancadopaciente/ index.php/publicacoes/category/relatorios-dos-estados.

5. Simão CMF, Caliri, MHL, Santos CB. Concordância entre enfermeiros quanto ao risco dos pacientes para úlcera por pressão. Acta Paul Enferm. 2013;26(1):30-5. doi: 10.1590/S0103-21002013000100006

6. Alves AGP, Borges JWP, Brito MA. Avaliação do risco para úlcera por pressão em unidades de terapia intensiva: uma revisão integrativa. Rev Pesqui Cuid Fund. 2014;6(2):793. doi: 10.9789/2175-5361.2014v6n2p793

7. Associação Brasileira de Estomaterapia. Associação Brasileira de Enfermagem em Dermatologia. Classificação das Lesões por Pressão Consenso NPUAP 2016 - Adaptada Culturalmente para o Brasil [Internet]. NPUAP - National Pressure Ulcer Advisory Panel, 20162017 [cited 2019 May 24]. Available from: http://www.sobest.org.br/textod/35

8. Albuquerque AM, Souza MA, Torres VSF, Porto VA. Soares MJGO, Torquato IMB. Avaliação e prevenção da úlcera por pressão pelos enfermeiros de terapia intensiva: Conhecimento e prática. Rev Enferm UFPE. 2014;8(2):229-39. doi: 10.5205/1981-8963-v12i6a234578p1738-1750-2018

9. Soares P0, Machado, TMG, Bezerra SMG. Uso da escala de Braden e caracterização das úlceras por pressão em acamados hospitalizados. Rev Enferm UFPI. 2015;4(3):18-23. doi: 10.26694/reufpi.v4i3.3437

10. Diniz, SMO, Martins Sobrinho GK, Oliveira RW, Viana KRJ, Nery FS. Prevalência de Úlcera por Pressão em Unidade de Terapia Intensiva em Hospitais Públicos. In: Anais do I international nursing congress Theme: Good practices of nursing representations in the construction of society [Internet]. Brasil, Espanha, 2017[cited 2019 May 24]. p. 1-4. Available from: https://eventos.set.edu.br/index.php/cie/article/view/5804

11. Alves CR, Costa LM, Boução DMN. Escala de Braden: a importância da avaliação do risco de úlcera por pressão em pacientes em uma unidade de terapia intensiva. Rev Recien[Internet]. 2016[cited 2019 May 24];6(17);36-44. Available from: http://recien.com.br/index.php/ recien/article/view/147

12. Pereira, MO, Ludvich, SC, Omizzolo, JE. Segurança do paciente: prevenção de úlcera por pressão em unidade de terapia intensiva. Inova Saúde. 2016;5(2):29-44. doi: 10.18616/is.v5i2.3009

13. Diagnósticos de enfermagem da NANDA: definições e classificação 2012-2014. Porto Alegre: Artmed, 2013.

14. Sardo P, Simões C, Alvarelhão J. Costa C, Simões JC, Figueira J et al. Pressure Ulcer risk assessment: retrospective analysis of Braden Scale scores in Portuguese hospitalized adult patients. J Clin Nurs. 2015;24(21-22):3165-7. doi: 10.1111/jocn.12927

15. Chen HI, Cao YJ, Wang J, Huai BS. Calibration power of the Braden scale in predicting pressure ulcer development. J Wound Care. 2016;25(11):102-13. doi: 10.12968/jowc.2016.25.11.655 
16. Ministério da Saúde (BR). Gabinete do Ministro. Portaria n 529, de $1^{\circ}$ de abril de 2013. Institui o Programa Nacional de Segurança de Paciente (PNSP). [Internet]. 2013 [cited 2019 May 24]. Available from: http://bvms.saude.gov.br/bvs/saudelegis/gm/2013/ prt0529_01_04_2013.html

17. Medeiros LNB, Silva DR, Guedes CDFS, Souza TKC, Neta BPAR. Prevalência de úlceras por pressão em unidades de terapia intensiva. Rev Enferm UFPE. 2017;11(7):2697-703. doi: 10.5205/reuol.10939-97553-1-RV.1107201707

18. Borghardt AT, Prado TN, Araújo TM, Rogenski NMB, Bringuente MEO. Avaliação das escalas do risco de úlcera por pressão em pacientes críticos: uma coorte prospectiva. Rev Latino-Am Enfermagem. 2015;23(1):28-35. doi: 10.1590/0104-1169.0144.2521

19. Instituto de pesquisa econômica aplicada IPEA. Políticas Sociais - acompanhamento e análise n 20, Capítulo 8, Brasília (DF); 2012.

20. Rogenski, NMB, Kurcgant P. Incidência de úlceras por pressão após a implementação de um protocolo de prevenção. Rev Latino-Am Enfermagem. 2012;20(2):333-9. doi: 10.1590/S0104-11692012000200016

21. Ribeiro JB, Santos JJ, Santana NA, Fraga IMN, Nery FS. Principais fatores do risco de desenvolvimento de lesão por pressão em unidades de terapia intensiva. Cad Grad Ciên Biol Saúde [Internet]. 2018 [cited 2019 May 24];5(1):91-102. Available from: https://periodicos.set.edu.br/ index.php/cadernobiologicas/article/view/5278/3002

22. Almeida DV, Oliveira KF, Oliveira JF, Pires NF, Filgueira VSA. Diagnósticos de enfermagem mais frequentes em pacientes internados na Unidade de Terapia Intensiva Coronariana. Arq Med Hosp Fac Cienc Med [Internet]. 2013 [cited 2019 May 24];58(2):64-9. Available from: http://arquivosmedicos.fcmsantacasasp.edu.br/index.php/AMSCSP/article/view/225

23. Ferreira AM, Rocha EN, Lopes CT, Bachion MM, Lopes JL, Barros ALBL. Diagnósticos de enfermagem em terapia intensiva: mapeamento cruzado e Taxonomia da NANDA-I. Rev Bras Enferm. 2016;69(2):285-293. doi: 10.1590/0034-7167.2016690214i

24. Petz FFC, Crozeta K, Meier MJ, Lenhani BE, Kalinke L P, Pott SD. Úlcera por pressão em unidade de terapia intensiva: estudo epidemiológico. Rev Enferm UFPE. 2017;11(1);287-95. doi: 10.5205/1981-8963-v11i1a11907p287-295-2017

25. Canada Patient Safety Institute. The Safety Competencies: enhancing patient safety across the health professionals [Internet]. 2008 [cited 2019 May 24]. Otawa, ON: Canada Patient Safety Institute. Available from: https://www.patientsafetyinstitute.ca/en/toolsResources/ safetyCompetencies/Pages/default.aspx 